\title{
Bauhaus Dokuma Atölyesi'nden Bir Kesit: Anni Albers, Otti Berger, Gunta Stölzl
}

\section{A Section from the Bauhaus Weaving Workshop: Anni Albers, Otti Berger, Gunta Stölzl}

Nuray Er Bıyıklı, Tekstil ve Moda Tasarımı Bölümü, Mimar Sinan Güzel Sanatlar Üniversitesi

Kenan Saatçıŏlu, Tekstil ve Moda Tasarımı Bölümü, Süleyman Demirel Üniversitesi

\begin{abstract}
Özet
18. yüzyılın ikinci yarısında Birleşik Krallık'ta ortaya çıkan Sanayi Devrimi, gelișen makineleșme süreci ile birlikte erken dönemlerinden itibaren tekstil üretimi üzerinde önemli derecede etkili olmuştur. Sanayi Devrimi'nden sonra tekstil tasarımcısı William Morris öncülügünde ortaya konulan Arts and Crafts Hareketi, tekstil endüstrisi için önemli olan tekstil tasarımı süreçlerine farklı bir bakış açısı kazandırmıștır. Sanayi Devrimi ve Arts and Crafts Hareketi'nin yansımalarından beslenen ve 20. yüzyılın bir ihtiyacı olarak oluşan modern tasarım anlayıșı doğrultusunda bir okul olarak 1919 yılında kurulan Bauhaus Sanat ve Tasarım Okulu bünyesinde yer alan Dokuma Atölyesi, endüstriyelleşme sürecinde tekstil tasarımına öncülük etmiş ve büyük katkılar sağlamıștır. Özellikle mevcut atölyede çalışan öğrenci ve akademisyenler, dokuma tasarımı alanında belirtilen dönem için çok önemli görülen ve endüstriyel anlamda değer taşıyan dokuma kumaş tasarımı örneklerini yansıtmıșlardır. Bu çalıșmada, tarihsel süreç içerisinde Sanayi Devrimi'nin tekstil tasarımına etkilerinin yansımaları ile birlikte Bauhaus Sanat ve Tasarım Okulu bünyesinde yer alan Dokuma Atölyesi'nin tanıtılması amaçlanmıştır. Mevcut amaç doğrultusunda ayrıca belirtilen atölyede hem öğrencilik hem de akademisyenlik yapmıș olan Anni Albers, Otti Berger ve Gunta Stölzl adlı öncü kadın tekstil tasarımcıları hakkında bilgiler verilmiş, bu tasarımcıların endüstriyel bakış açısı doğrultusunda üretmiş oldukları dokuma kumaş tasarımları değerlendirilmiştir. Betimsel araştırma yöntemlerinden tarama yönteminin kullanılmıs olduğu çalıșmanın, Sanayi Devrimi'nin tekstil tasarımına etkilerini göstermesinin yanı sıra Bauhaus Sanat ve Tasarım Okulu bünyesinde yer alan Dokuma Atölyesi ve bu atölyeden çıkan üç farklı tasarımcının endüstriyel bağlamda üretmiş oldukları dokuma tasarımlarını yansıtması açısından önem taşıdığı düşünülmektedir.
\end{abstract}

Anahtar Sözcükler: Bauhaus, dokuma tasarımı, endüstriyelleşme, tekstil tasarımciları.

Akademik disipin(ler)/alan(lar): Tekstil ve moda tasarımı, tekstil tarihi.

\begin{abstract}
The Industrial Revolution that emerged in the United Kingdom in the second half of the 18th century, along with the developing mechanization process, had a significant impact on textile production. The Arts and Crafts Movement, which was associated with textile designer William Morris after the Industrial Revolution, brought a different perspective to the textile design processes that are important for the textile industry. The Bauhaus was founded in 1919 to reflect a modern design approach in the light of both the Industrial Revolution and the Arts and Crafts Movement. In the industrialization process, the Weaving Workshop of the Bauhaus pioneered textile design and made great contributions to this field. The students and academicians who formed part of the workshop produced examples of woven fabric design, which were considered very important and valuable for this period in the field of weaving design. This study aims to introduce the Weaving Workshop of the Bauhaus along with some reflections on the effects of the Industrial Revolution on textile design in the historical process. It explores and evaluates the work of the leading women textile designers Anni Albers, Otti Berger and Gunta Stölzl, who were both students and academicians. In the study, a scanning method was employed as one of the descriptive research methods. The study is important in terms of showing the effects of the Industrial Revolution on textile design as well as reflecting upon the weaving designs produced industrially by the Weaving Workshop of Bauhaus and three different designers who worked in this workshop.
\end{abstract}

Keywords: Bauhaus, weaving design, industrialization, textile designers.

Academical disciplines/fields: Textile and fashion design, textile history.

- Sorumlu Yazar: Kenan Saatçığlu, Tekstil ve Moda Tasarımı Bölümü, Süleyman Demirel Üniversitesi

- Adres: Süleyman Demirel Üniversitesi Güzel Sanatlar Fakültesi, Ertokuş Bey Derslikleri İçi, Doğu Yerleşkesi 32200, Çünür, Isparta

- e-posta: saatciogluk@gmail.com

- ORCID: 0000-0002-1026-1090

- Çevrimiçi yayın tarihi: 30.05 .2021

- doi: $10.17484 /$ yedi.886237 


\section{Giriș}

18. yüzyılın ikinci yarısında Birleșik Krallıkta ortaya çıkan ve devam eden süreçte öncelikle Kıta Avrupası ve Kuzey Amerika gibi bölgelerde görülerek tüm dünyayı hızla etkisi altına alan Sanayi Devrimi, endüstriyelleşme kavramını gündeme getirmiş, böylece birçok üretim alanının hızla gelişmesini sağlamıştır. Gün geçtikçe gelişen ve sayıca artış gösteren makineleşme sayesinde önceki dönemlere kıyasla daha ilkel şartlarda gerçekleştirilen üretim süreçleri, yerini daha yenilikçi bir yapıya bırakmıştır. Bu durum var olan teknik altyapının gelişmesinin yanı sıra yenilikçi malzemelerin bulunmasıyla da birçok alanda daha önce rastlanılmamış ürünlerin ortaya çıkmasını desteklemiştir. Bilhassa tekstil üretimi mevcut dönemde endüstriyelleşmenin itici gücünü oluşturmuş, böylece hem giyim hem de iç mekân tekstilleri açısından çağın koşul ve ihtiyaçlarına uyum sağlayabilecek tekstil ürünlerinin geliştirilip gün ışığına çıkarılacağı yeni bir dönemin kapısı aralanmıştır.

Sanayi Devrimi'nin etkisiyle sürekli bir gelişim içerisinde olan tekstil endüstrisi, 1880'li yıllarda tekstil tasarımcısı kimliğiyle öne çıkan William Morris'in öncülüğünde gerçekleştirilen Arts and Crafts Hareketi ile endüstriyelleşmenin zaman içerisinde getirmiş olduğu üretim biçimlerinden kaynaklanan monotonluğa ve sıradanlığa savaş açarak, zanaat kavramını öven yaklaşımıyla tekstil tasarımı süreçlerine farklı bir boyut kazandırmıştır (Aslan, 2015, s. 40; Gürcüm, 2019, s. 189). William Morris, doğadan iham aldığı bitki ve hayvan motiflerinin bir araya getirilmesiyle oluşturduğu girift bir zariflikte olan tekstil tasarımı örnekleri ile makineleşmenin karşısında el işçiliğini savunan bir anlayışı benimsemiştir. Sanat ve zanaat kavramlarını ayrılmaz bir bütünün parçaları olarak değerlendiren tasarımcı, mevcut dönemde özellikle iç mekân tekstil ürünlerinde kullandığı dokuma ve baskı teknikleri ile yaşam alanlarına farklı bir dokunuş yapmayı başarmıştır (Jackson, 2002, s. 10).

Sanayi Devrimi gibi Birleşik Krallık'ta ortaya çıkan Arts and Crafts Hareketini devam eden süreçte Fransa'da Art Nouveau, Almanya'da Jugendstil ve Avusturya'da Sezessionstil gibi sanat ve tasarım hareketleri takip etmiştir (Gür Üstüner, 2018, s. 237). Bu hareketler uygulamalı atölye eğitimi veren okulların açılmasına da ilham kaynağı olmuş ve mevcut dönemde Avrupa genelini etkilemeyi başarmıştır (Arslan, 2019, s. 344). İfade edilen bu hareketler mevcut dönemde birçok sanat ve tasarım disiplinini etkilediği gibi endüstriyel bir alan olarak konumlanmış tekstil tasarımını da oldukça etkilemiştir. Bu bağlamda bilhassa Avrupa genelinde tekstil tasarımı açısından da büyük önem taşıyan okullar açılmıştır. Tekstil tasarımı eğitimini uygulamalı bir bakış açısıyla değerlendiren bu okullar ele alındığında; Omega Workshops, Wiener Werkstätte ve Atelier Martin gibi kuruluşları mevcut okullara örnek olarak göstermek mümkün olacaktır (Özay, 2001, s. 25).

Sanayi Devrimi ile başlayan süreç birbirini zaman içerisinde destekleyen sanat ve tasarım hareketleri ile birlikte, 20. yüzyılın ilk yarısında modernizm anlayışının ortaya çıkmasına olanak sağlamıştır. Modernizm doğrultusunda, estetik ve fonksiyonel kavramların göz önünde bulundurulduğu yeni, yaratıcı ve sorgulayıcı bir tasarım ihtiyacı ortaya çıkmıştır (Acar, 2013, s. 81). İçinde bulunulan çağın adeta bir gereksinimi olan bu bakış açısı, uygulamalı sanatlar ile güzel sanatlar arasında bulunan duvarı ortadan kaldırmayı hedefleyen bir eğitim anlayışına zemin hazırlamıştır (Erkmen, 2009, s. 17). Bu bağlamda, tekstil tasarımı eğitimi açısından da büyük bir öneme sahip olan Bauhaus Sanat ve Tasarım Okulu kurulmuştur. 1919 yılında Almanya'da kurulan bu okulun bünyesinde yer alan Dokuma Atölyesi'nde birçok tekstil tasarımcısının yetiştiği ve bu tasarımcıların tekstil tasarımı alanına büyük katkılar sağladıkları görülmektedir. Özellikle, Bauhaus Sanat ve Tasarım Okulu bünyesinde yer alan Dokuma Atölyesi'nde öğrencilik yapmıș ve daha sonra tekrar bu atölyede akademisyen olarak çalıșma fırsatı elde etmiș Anni Albers, Otti Berger ve Gunta Stölzl adlı tekstil tasarımcılarını ayrı bir yere koymak gerekmektedir. Bauhaus Sanat ve Tasarım Okulu Dokuma Atölyeleri araştırılırken, bu öncü kadın tekstil tasarımcılarının endüstriyel bir bakış açısıyla özgün dokuma kumaş tasarımları ürettikleri ve dönemin tekstil endüstrisine yenilikçi bir bakış açısı kazandırdıkları dikkat çekmektedir.

Bu çalışmada tarihsel süreç içerisinde Sanayi Devrimi sonrası tekstil tasarımının gelişimi ve bu gelişimle birlikte ortaya çıkan etkileşimlerin yanı sıra Bauhaus Sanat ve Tasarım Okulu bünyesinde yer alan Dokuma Atölyesi ve bu atölyenin öğrencisi olmuş üç farklı tekstil tasarımcısının tanıtılması amaçlanmıştır. Mevcut amaç doğrultusunda belirtilen atölyede hem öğrencilik hem de akademisyenlik yapmış olan Anni Albers, Otti Berger ve Gunta Stölzl adlı öncü tekstil tasarımcıları hakkında bilgiler verilmiş, ayrıca bu tasarımcıların endüstriyel bakış açısı doğrultusunda üretmiş oldukları dokuma kumaş tasarımları hakkında bilgiler verilerek mevcut dokuma kumaş tasarımlarına ilişkin yaklaşımları değerlendirilmiştir. Betimsel araştırma yöntemlerinden tarama yönteminin kullanılmış olduğu çalışmada, alana ilişkin detaylı bir kaynak araştırması yapılmış ve elde edilen verilerin derlenmesiyle birlikte araştırmanın sonucuna ulaşılmıştır. 
Çalışmanın, Sanayi Devrimi sonrasındaki gelişmelerin tekstil tasarımına etkilerini göstermenin yanı sıra Bauhaus Sanat ve Tasarım Okulu bünyesinde yer alan Dokuma Atölyesi ve bu atölyeden çıkan öncü üç tekstil tasarımcısı ile bu tasarımcıların endüstriyel bağlamda üretmiş oldukları dokuma kumaș tasarımlarını yansıtması açısından önem taşıdığı düşünülmektedir.

\section{Sanayi Devrimi'nin Tekstil Tasarımına Etkileri}

Sanayi Devrimi ile geçmiș dönemlere kıyasla farklı bir yapıya bürünen yeni yașam anlayıșı, mevcut dönemde gözlemlenen teknolojik gelişmeler sonucunda teknik bir dünya yaratmış (İșpiroğlu ve İsspiroğlu, 1979, s. 15), böylece endüstriyelleşmenin gün geçtikçe yașam alanlarına dâhil olma süreci hızlanmıștır. Endüstriyelleşmenin hızla günlük yaşam içerisinde yer edinmesi, insan ve makine gücünün bir arada işleyeceği sosyo-ekonomik bir düzenin kurulması ile birlikte, toplumsal anlamda farklı gelişmeleri de beraberinde getirmiştir. Önceki zaman dilimlerinde üretim ortamlarında egemen konumda olan küçük atölyeler, yerini buhar gücü ile çalışan makinelerden oluşan büyük üretim tesislerine bırakarak, insan faktörünün üretim içerisindeki etkinliğini kısıtlamıştır. Acar (2004, s. 92) bu durumu; "makineleşmenin hızla çoğalması ile beliren ortam üretim hızının artmasına neden olmuş, böylece artan üretim hızı ortaya çıkan yeni ekonomik sınıfların satın alma hareketlerinde değişiklik göstermesine olanak sağlamış ve satış miktarını arttırmaya dayalı bir üretim anlayışı benimsenmiştir" şeklinde ifade etmektedir.

Değişiklik gösteren üretim anlayışıyla birlikte şekillenen bu ortamda istihdam, değer, sermaye gibi çıktılar bakımından Sanayi Devrimi'nin en belirgin endüstrisinin tekstil endüstrisi olduğu karşımıza çıkmaktadır. Bununla birlikte tekstil endüstrisi, çağın gereksinimi olan modern üretim yöntemlerini kullanan ilk endüstri olarak da diğer endüstrilerden ayrışmaktadır (Landes, 1988, s. 40). Mevcut zaman diliminde Birleşik Krallıkta ortaya çıkan teknolojik anlamdaki yeni buluşlar, tekstil endüstrisi adına önemli adımların atılması sağlamıştır. 1733 yılında bir fabrika işçisi olan John Kay tarafından icat edilen ve Flying Shuttle adı verilen sistem, dokuma tezgâhlarının daha hızlı bir şekilde çalışmasına olanak sağlamıștır (Espinasse, 1874, s. 330). Dokuma tezgâhlarının daha hızlı çalışması iplik ihtiyacına olan talebi artırmıș, bu talep doğrultusunda 1766 yılında James Hargreaves birkaç ipliği aynı anda eğirebilen Spinning Jenny adı verilen iplik eğirme makinesini icat etmiştir (Timmins, 1993, s. 18). Tekstil endüstrisindeki yenilikler devam ederken bu yenilikleri; 1769 yılında Richard Arkwright'a ait Water Frame adı verilen ve 1779'da Samuel Crompton'a ait Spinning Mule adı verilen iplik eğirme makinelerinin buluşları takip etmiştir (Baines, 1835, s. 199; Fitton, 1989, s. 119). Edmund Cartwright'in mucidi olduğu Power Loom adı verilen su gücüyle çalışan dokuma tezgâhı ise 1785 yılında icat edilerek dokuma sanayine daha da ivme kazandırmıștır. Mevcut dönemde ortaya konulan bu teknolojik gelişmelerin tümü tekstil endüstrisinde uzun yıllar kullanılmış, hem pamuklu hem de yünlü dokuma kumaşların gelişimine büyük katkılar sağlamıştır (Günay, 2002, s. 13; Marsden, 1895, s. 61).

Sanayi Devrimi süresince tekstil endüstrisi için fark yaratan bulușların çoğu Birleșik Krallık menșeili olsa da özellikle Sanayi Devrimi'nin ilerleyen dönemlerinde Kıta Avrupası'nda ve Amerika Birleşik Devletleri'nde tekstil endüstrisi için önemli buluşların ortay çıktığı da görülmektedir. Bu icatlar ele alındığında, 1794 yılında Amerika Birleşik Devletleri'nden Eli Whitney'in Cotton Gin adı verilen çırçır makinesini icat etmesi pamuklu dokumalara olan talebi daha da arttırmıştır (Hounshell, 1985, s. 29). Bunun yanı sıra günümüz dokuma kumaş üretiminde hala çok önemli bir yeri olan ve 1801 yılında Fransa'dan Joseph Marie Charles (Jacquard) tarafından ortaya konulan Jacquard Loom adı verilen dokuma tezgâhı icat edilmiştir. Mevcut dönemde hâlihazırda kullanılmakta olan dokuma tezgâhlarından çok daha farklı bir teknolojiye sahip olan bu dokuma tezgâhları, sahip olduğu kart sistemi sayesinde daha detaylı, yoğun ve büyük desenlerin ortaya çıkarılmasına izin vermiștir (Essinger, 2004, s. 33). Devam eden süreçlerde tekstil endüstrisinde birbirini takip eden icatlar, dokuma sanayiinin gelişmesi ile örme ve kimya alanlarının da gelişimini tetiklemiş ve böylece bu alanların da tekstil endüstrisinde edindiği konumları güçlendirmiştir (Gür Üstüner, 2017, s. 50).

Tekstil endüstrisinde teknolojinin gün geçtikçe gelişmesiyle makinelerin insan eliyle yapılmakta zorlanılan ürünleri kısa bir sürede yapabilmesi farklı renklerde, dokularda ve tekniklerde yapılmış tekstil ürünlerinin tüketicilerle hızlı bir şekilde buluşmasına olanak sağlamıștır. Fakat seri üretimin bir getirisi olan monotonluk duygusu, belirli bir süre sonra toplulukların güzellik anlayıșının değişmesine sebep olmuştur. Özellikle mevcut zaman dilimde üretilen tekstil ürünleri tasarım boyutları doğrultusunda ele alındığında, bu ürünlerin tasarım anlamında yeterli derecede değer taşımadığı ve üretim hızıyla birlikte gereken özenden yoksun bir şekilde üretildiği gibi tartışmaları da beraberinde getirmiştir. Bu durumu Read (1973) şu şekilde yorumlamıştır; 
(...) makine çağı bütün gücü ve anlamıyla tam ve kesin olarak yerleșmiștir. Makine ve estetik arasındaki problemler bu çağla birlikte başlamıştır. Makine bir ucundan hammaddeleri yiyip öbür ucundan bitmiş eşyayı çıkaran bir canavardı. Ancak bitmiş eşyanın zarafeti, süsü ve rengi ile alıcılara cazip gelmesi gerekiyordu tecrübelerimiz ışığında yaklaşmamız kaçınılmazdır. (Read, 1973, s. 18)

Mevcut bakış açısı, Sanayi Devrimi'nin yarattı̆̆ sıradanlık hissi ile var olan sanat ve tasarım ortamının sorgulanmasına neden olmuştur. Böylece 19. yüzyılın son dönemlerine doğru Britanya Adaları'nda ortaya çıkan ve devam eden zaman diliminde Avrupa ve Amerika kıtasına yayılan bir sanat ve zanaat hareketi ortaya çıkmıştır. Arts and Crafts adı verilen bu hareket, dekoratif sanatların yansıttığı algıların yoksullaşmasına ve mevcut üretim koşullarına tepki olarak mimar ve tasarımcı Augustus Welby Northmore Pugin, yazar ve sanat eleștirmeni John Ruskin, tekstil tasarımcısı ve sanatçı William Morris tarafından ortaya çıkarılmıştır (Campbell, 2006, s. 48).

Sanayi Devrimi ile birlikte oluşan estetik ve yaratıcılıktan yoksun olan mekanik düzene karşı olan bir anlayışla ortaya çıkan Arts and Crafts Hareketi'nin tekstil tasarımı üzerinde önemli bir etkiye sahip olduğu görülmüştür. Bu hareketin öncü isimlerinden tekstil tasarımcısı William Morris'in büyük bir özenle hazırlanmış desenleri, bilhassa iç mekân tekstilleri olarak adlandırılabilecek döşemelik ve perdelik kumaşların yanında bu mekânların birer tamamlayıcısı konumundaki duvar kâğıtlarında da hayat bulmuştur. William Morris, ortaya koyduğu desenlerde doğayı çok iyi gözlemlemiştir. Doğanın birbirinden ayrılamaz bütünlüğünü oluşturan çeşitli bitki, çiçek, tohum ve hayvan gibi ilham aldığı unsurlara müthiş bir incelikle tasarımlarında yer vermiş ve bununla birlikte tasarımlarını üretmeden önce o tasarımı hangi üretim tekniği ile oluşturacağı konusunu detaylı bir şekilde ele almıştır (Parry, 1983, s. 8). Tasarımlarında adeta Ortaçağa ait mimari yapıların ince işçiliğine benzer detayları barındıran tasarımcı, özellikle tekstil ürünlerinde açık ve kızıl kahverengi, yosun yeşili ve sarı tonlarını büyük bir ustalıkla kullanmıştır (Anscombe, 1991, s. 184). Dönem içerisinde William Morris ve arkadaşları Morris\& Co. adını verdikleri bir şirket kurmuşlar ve dönemin aristokratları ve önde gelenleri için tekstil tasarımı ürünleri üretmişlerdir. Şirketin ortaya koyduğu kumaş tasarımlarında görüleceği gibi, William Morris ve arkadaşları Sanayi Devrimi ile birlikte kullanılmaktan vazgeçilen nakış, doğal boyamacılık ve blok baskı gibi teknikleri kullanmakta ısrar etmişlerdir (Parry, 1983, s. 6-9). Böylece Sanayi Devrimi'nin yaratmış olduğu mekanik ve monoton ortamda, Arts and Crafts Hareketi ile zanaatın gücü ortaya çıkartılmış ve tekstil tasarımına ilişkin eşsiz işlere imza atılmıştır.

20. yüzyılın başlarında Arts and Crafts Hareketini Avrupa kıtasında farklı bölgelerde Art Nouveau, Jugendstil, Sezessionstil gibi isimlerde sanat ve tasarım hareketlerinin takip ettiği, tasarımı destekleyen bu hareketlerin etkisiyle endüstriyel üretimde ürüne yaklaşımın değişiklik gösterdiği söylenebilir. Fakat 1914-1918 yılında Avrupa kıtası genelinde patlak veren I. Dünya Savaşı, toplumsal ve ekonomik dengeleri değiştirdiği gibi sanat ve tasarım alanında da yerini yeni bir anlayışın benimseneceği bir düzene bırakmıştır. I. Dünya Savaşı'ndan sonra önceki zaman diliminde etkin yapıda olan Arts and Crafts Hareketi ile zanaat kavramının ön plana çıktığı anlayış, savaştan sonraki süreçte tasarımcı ve makine arasında ilişki kuran bir anlayışa bırakmıştır (Jackson, 1998, s. 14). Modernizm olarak adlandırılan bu anlayış, diğer alanlarda olduğu gibi tekstil endüstrisinde de var olan yapıyı değiștirmeye başlamıştır. Mevcut süreçle birlikte ortaya çıkan tekstil tasarımı kavramı ile ürünlerde detaylı ve süslü kullanım azalırken, geometrik ve soyut desenler ön plana çıkmış ve bununla birlikte tasarımlarda estetik kaygı ile birlikte işlevsellik olgusu da aranmaya başlanmıştır.

Modernizm kavramı ile birlikte özellikle Avrupa'da gelişen sanat ve tasarım anlayışı, sanat ve tasarım eğitimi veren okulların açılmasına öncülük etmiştir. Çağın gereksinimine uygun olan modern ve işlevsel ürün tasarımları geliştirilebilecek tasarımcılar yetiştirmeyi ilke edinmiş bu okullardan en önemlisinin Bauhaus Sanat ve Tasarım Okulu olduğu görülmektedir. Tasarım tarihi açısından da büyük bir değere sahip olan bu okulun bünyesinde yer alan Dokuma Atölyesi, bu atölyeden yetişen tekstil tasarımcıları ve bu tasarımcıların ürettiklerinin endüstriyel üretim açısından öncülük ederek önemli bir yer edindiği görülmüştür. Bu bağlamda, Sanayi Devrimi ile başlayan ve Arts and Crafts Hareketi ile devam eden tekstil tasarımının uzun serüveni, Bauhaus Sanat ve Tasarım Okulu bünyesinde yer alan Dokuma Atölyesi ile çağımızda da büyük önem taşıyan endüstri-tekstil tasarımcısı ilişkisinin doğru konumlanmasını ve başarılı sonuçlar elde edilmesini desteklemiştir. 


\title{
3. Bauhaus Sanat ve Tasarım Okulu
}

Arts and Crafts Hareketi'nden ilham alarak Almanya'nın Weimar kentinde 1906 yılında sanatçı ve tasarımcı Henry van de Velde tarafından Saksonya Grandüklügü Uygulamalı Sanatlar Okulu (GroßherzoglichSächsische Kunstgewerbeschule) adında bir sanat ve tasarım okulu kurulmuştur. I. Dünya Savaşı ile gelişen sosyal ve siyasi ortam bu okulun kurucusu Belçikalı Henry van de Velde'nin Almanya'yı terk etmesine neden olmuştur. Böylece ülkeyi terk eden sanatçl, okulun yönetimine geçmesi için mimar Walter Gropius'u önermiș ve daha sonraki süreçte de mevcut okulun yönetimini bu kişi devralmıștır (Gür Üstüner, 2018, s. 238; Droste, 2002, s. 16). Okulun yönetimini devralan Walter Gropius, Saksonya Grandüklügü Plastik Sanatlar Okulu (Großherzoglich-Sächsische Kunstschule) ve Saksonya Grandüklügü Uygulamalı Sanatlar Okulu (Großherzoglich-Sächsische Kunstgewerbeschule) adlı okulları birleştirerek Bauhaus Sanat ve Tasarım Okulu'nu (Staatliches Bauhaus) kurmuştur (Forgács, 2017, s. 41).

Sanat ve tasarım süreçleri içerisinde yer alan yaratıcı çabaları bir bütün halinde bir araya getirmeyi ve uygulamalı sanatların tüm disiplinlerini bir bütünün parçası olarak değerlendirerek bir alanda uzmanlaşmayı ilke edinen bu okul, sanat ve zanaat kavramlarının bir arada kurgulanmasının gerekliliğini vurgulamaktaydı. Walter Gropius tarafından savunulan ve okulun manifestosunda ifade edilmiş olan bu düşünceyi Yaylalı (2000) şu şekilde aktarmıştır;

\begin{abstract}
(...) Walter Gropius tarafindan kurulan Bauhaus Sanat ve Tasarım Okulu, Orta Çă̆'daki meslek loncalarının var olduğu dönemdeki gibi mutlu bir çalışan sınıf yaratmayı planlamıștır. 1919 yılında yayınlanan manifestoda geniş ölçekli ortak projeler gerçekleştirebilecek nitelikte insanları eğitmek için, güzel sanatlar, mimari ve uygulamalı sanatların birleștirilmesinin gerekliliği savunulmuştur. 'Mimar, heykeltıraş ve ressamlar, hepimiz zanaata dönmek zorundayı. Sanat denilen şey bir meslek sayılmaz. Sanatçı ile zanaatçı arasında esaslı bir fark gözetilemez. Sanatçı vecde kapılmış bir zanaatçıdır. Aslında her sanatçıya lazım olan şey zanaatında maharet sahibi olmasıdır. Bu maharet bir nevi yaratıcı düşünce kaynağıdır. 0 halde zanaatçı ile sanatçı arasında mağrur bir perde yaratan sınıf ayırımı düşüncesinden arınmış yeni bir zanaatçılar loncası kuralım. Mimariyi heykeli ve resmi bir bütün halinde kapsayabilecek günün birinde yepyeni bir inancın kristal sembolü olarak milyonlarca işçinin elinden göğe yükselecek geleceğin mimarisini beraberce tasarlayıp yaratalım' diyen Gropius'un manifestosu, sanat ve zanaat arasında kurulacak birlik, bütünlük ve iş birliğine bir çağrı niteliği taşımaktadır. (Yaylalı, 2000, s. 108)
\end{abstract}

Bauhaus Sanat ve Tasarım Okulu'nun eğitim içerikleri ele alındığında, okulun sahip olduğu atölye sistemiyle öğrencilerini belirlenen bir sanat veya tasarım alanında uzmanlaştırdığı ortaya çıkmaktadır. Alanında mesleki açıdan önemli bir yere sahip olan dönemin sanatçı, tasarımcı ve mimarların öncülüğünde yürütülen atölye derslerinin, temel tasarım ve çeşitli kuramsal derslerle desteklendiği ile karşılaşılmaktadır (Siebenbrodt \& Schöbe, 2009, s. 13). Bunun yanı sıra okulda farklı sanat veya tasarım alanları ile ilgili atölyelerin olduğu ve bu atölyelerde eğitim alacak öğrencilere öncelikle atölyede yer alan malzeme, araç ve gereçlerin iyice tanıtıldığı; sonrasında ise öğrencilere dönemin ihtiyaçlarını karşılayan nitelikli ve modern tasarım ürünleri üretmeye yönelik uygulamalı öğretilerin aktarıldığı görülmektedir. Okulun sahip olduğu atölyelere bakıldığında ahşap, dokuma, duvar tasarımı, fotoğraf, gravür, metal, mimarlık, sahne tasarımı, seramik, tipografi ve grafik gibi atölyelerin varlığından söz edilebilir (Bilgin, 2009, s. 104; Gropius, 2002, s. 53-105).

Bauhaus Sanat ve Tasarım Okulu 1919-1933 yılları arasında faaliyet göstermiş, farklı sanat ve tasarım alanlarında birçok sanatçı ve tasarımcının yetişmesinde çok önemli bir yer edinmiştir. Bu isimler arasında kurucu müdür Walter Gropius'un (mimar) yanı sıra; Ludwig Mies van der Rohe (mimar), László MoholyNagy (ressam, heykeltıraş, fotoğraf sanatçısı), Marianne Brandt (endüstri ürünleri tasarımcısı), Wassily Wassilyevich Kandinsky (ressam), Paul Klee (ressam), Josef Albers (ressam), Oskar Schlemmer (ressam, heykeltıraş, dekor tasarımcısı) gibi öncü isimler gösterilebilir (Yaşar, 2019, s. 134).

Mevcut dönemde ortaya çlkan siyasi olaylar sonucunda okul farklı tarihlerde Weimar (1919-1925), Dessau (1925-1932) ve Berlin (1932-1933) gibi Almanya'nın farklı bölgelerinde konumlanmak zorunda kalmıştır. 1933 yılında kapanan kurumda çalışan akademisyenlerin birçoğu ise II. Dünya Savaşı'nın yaklaşan gergin siyasi ortamından kaçarak Amerika Birleşik Devletleri, Birleşik Krallık, Estonya, Hollanda, İsviçre, Macaristan, Türkiye gibi ülkelere sığınmışlar, bu ülkelerde mesleki ve akademik yaşantılarını devam ettirmişlerdir (Gürcüm, 2019, s. 192). 


\section{Dokuma Atölyesi ve Tasarımcılar}

Bauhaus Sanat ve Tasarım Okulu bünyesinde yer alan Dokuma Atölyesi'nin, yetiştirdiği tekstil tasarımcıları ve bu tasarımcıların bilhassa endüstriyel bağlamda ortaya koydukları dokuma kumaş tasarımları ile dönemin tekstil endüstrisi için öncü bir niteliğe sahip olduğu karşımıza çıkmaktadır. Okulun en verimli atölyelerinden birisi olarak gösterilebilecek bu atölye, okulun eğitim faaliyetlerine devam ettiği 14 yl boyunca üretimini aksatmadan sürdürmüş tek atölye olma özelliğine de sahiptir (Weltge, 1993, s. 16). Kız öğrenci çoğunluğunun olduğu Dokuma Atölyesi'nin fiziki şartları ele alındığında mevcut atölyede eğitim alan öğrenciler, Saksonya Grandüklüğü Uygulamalı Sanatlar Okulu'ndan kalma tezgâh ve teçhizatları kullanmışlardır. Saksonya Grandüklüğü Uygulamalı Sanatlar Okulu'nun yöneticisi olan Henry van de Velde zamanında okulun bu atölyesinden sorumlu olan dokuma branşı eğitmeni Helene Börner tarafından sonraki süreçte dokuma tezgâhları Bauhaus Sanat ve Tasarım Okulu'na kiralanmıştır. Bu dokuma tezgâhlarının yapılarına bakıldığında, armür yapılı dokuma tezgâhlarının yanı sıra atölyede jakar yapılı dokuma tezgâhların da bulunduğu ortaya çıkmaktadır (Gür Üstüner, 2018, s. 240).

Weimar, Dessau ve Berlin gibi okulun taşındığı farklı kentlerde yeniden yapılandırılmak zorunda kalan (Gürcüm ve Öneş, 2017, s. 406-410) Dokuma Atölyesi'nin, makine üretimine geçişte teorik ve pratik uygulamalarla endüstri için tasarımcı eğitimini ele aldığı ve tekstil alanında eksik olan tasarımcının yetiştirilmesi konusunu önemsediği görülmüştür. Bu bağlamda, atölyede verilen dokuma eğitiminin tasarımcının özgür tasarım anlayışına bırakılmış, farklı tekstil malzemelerine dayalı olan yenilikçi ve deneysel çalışmaları bulmaya yönelik bir içeriğe sahip olmuştur. Bununla birlikte armür yapısı içerisinde çözümlenebilecek geometrik kompozisyonların ortaya konulduğu endüstriyel dokuma çalıșmaları da atölye de sıklıkla ortaya konulmuştur (Gürcüm, 2019, s. 195). Bu yönüyle Bauhaus Sanat ve Tasarım Okulu bünyesinde bulunan Dokuma Atölyesi, günümüz tekstil endüstrisi için büyük bir yere sahip olan endüstriyel boyuttaki dokuma kumaş tasarımı açısından öncü bir geçmişe sahiptir. Akbostancı da (2014, s. 9) bu durumu; "modern anlamda tekstil tasarımı sürecinin sanat ve teknolojik gelişmeleri bir arada değerlendiren bu atölyede eğitim almıș olan tasarımcılar ile başlamıştır" görüşü ile desteklemiștir.

Johannes Itten, Georg Muche, Helene Börner, László Moholy-Nagy, Josef Albers gibi akademisyenler farklı zaman dilimlerinde ve farklı kentlerde konumlanmış Dokuma Atölyesi'ni yönetmişlerdir. Bunun yanında ressam olan Paul Klee ve Wassily Wassilyevich Kandinsky'nin ise Dokuma Atölyesi'nde bulunan öğrencilere renk, kompozisyon ve yüzeylerin sistematik bölünmeleri hakkında verdiği bilgiler öğrencilerin yapmış oldukları dokuma kumașlarda yer edinmiștir (Alyanak, 1998, s. 114). Böylece yaratılan dokuları, ana ve destekleyici renk tonlarının kullanımı, desenlerin yatay ve dikey kompozisyon kurguları ile ortaya konulan kumaşlar, o güne kadar pek de görülmemiş yenilikçi bir kumaş anlayışının gelişmesine katkı sağlamıştır (Gür Üstüner, 2018, s. 242; Özay, 2001, s. 27).

Dokuma Atölyesi'nde eğitim alan öğrencilerin Weimar'a göre Dessau'da daha geniş fiziksel olanaklara sahip oldukları görülmektedir. Bununla birlikte Dokuma Atölyesi gün geçtikçe teçhizat açısından daha da zenginleşmiştir. Sonraki süreçte ise Dokuma Atölyesi okulla birlikte Berlin'e taşınmış ve yaklaşı bir yıl gibi bir zaman diliminde bu kentte eğitim faaliyetlerine devam etmiștir (Gürcüm, 2019, s. 200-201).

Dokuma Atölyesi'nde eğitim veren akademisyenlere bakıldığında ise, akademisyenlerin çoğunun resim altyapılı olması ve herhangi bir tekstil eğitimi almamaları okul içerisindeki öğrenciler tarafından tartışılan bir konu olma durumunu yaratmıştır. Bu akademisyenlerin her birinden farklı tarzlarda elde edilmiş temel sanat eğitimi anlayışının deneysel ve yenilikçi içerikle buluşması farklı bir tasarım anlayışının gelişmesine fırsat vermiştir. Bu yenilikçi anlayış dönemin tekstil endüstrisine de öncülük ederek bu anlayıșın benimsemesini sağlarken, endüstriyel kumaş üretimi yapan Polytex firmasının dikkatini çekmiştir. Böylece Dokuma Atölyesi'nde oluşturulan dokuma kumaş tasarımı örnekleriyle, mevcut atölyede bu firma için metraj dokuma kumaş tasarımları üretilmeye başlamıştır (Weltge, 1993, s. 112).

Söz konusu dönemde dokuma atölyesinde öğrenci olan; Ani Albers, Gertrud Arndt, Lena Meyer-Bergner, Otti Berger, Marli Erhman, Margaret Leischner, Gunta Stölzl, Benita Koch-Otte, Margaretha Reichardt, Lis Beyer-Volger, Max Ppeiffer Watenpul, Margarete Willers ve diğerleri gibi kız öğrenciler bu atölyede aldıkları eğitimle oluşan altyapılarıyla tekstil tasarım tarihine yön veren tasarımları ile yenilikçi dokuma kumaş tasarımcıları olarak adlarından söz ettirmişlerdir. Özellikle adı geçen bu tasarımcılar ele alındığında, mevcut atölyede hem öğrencilik hem de akademisyenlik yapmış olan Anni Albers, Otti Berger ve Gunta Stölzl adlı tekstil tasarımcılarının armür ve jakar yapılı dokuma kumaş tasarımları ile 20. yüzyılın başında günümüz tekstil endüstrisine ışık tuttukları görülmektedir. 


\subsection{Anni Albers}

Asıl adı Annelise Elsa Frieda Fleischmann olan Anni Albers (Şekil 1), 1899 yılında Berlin'de dünyaya gelmiştir. Yayınevi sahibi bir aileye mensup olan bir annenin ve mobilya ustası olan bir babanın kızı olan Albers, çocukluk yıllarında görsel sanatlara oldukça ilgi duyarak büyümüştür (Brent, 2018). Varlıklı ve entelektüel bir aileden gelen Albers için mevcut dönemin koşullarında sanat eğitimi almak zor ve radikal bir karar olsa da, sanata olan ilgisi onun ilerleyen zamanlarda bu eğitimi almasını sağlamıştır. Böylece 1919 yılında Almanya'nın Hamburg kentinde yer alan Hamburg Uygulamalı Sanatlar Okulu'na (Kunstgewerbeschule Hamburg) girmeye hak kazanıp eğitimine başlamıştır. Bu okuldaki eğitiminden iki ay gibi kısa bir sürede vazgeçmiş ve 1922 yılında hayatının dönüm noktası olarak nitelendirilebilecek Bauhaus Sanat ve Tasarım Okulu'nda eğitim almaya başlamıştır (Reif, 1984, s. 8).

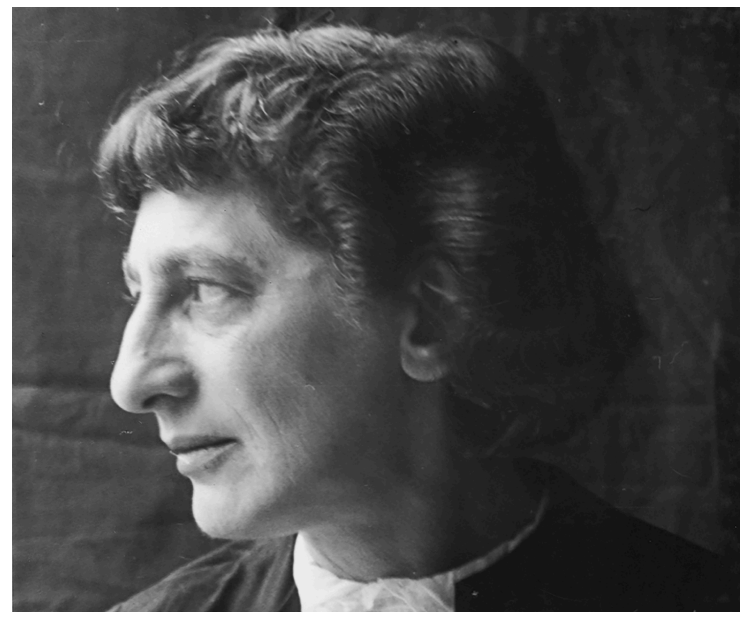

Şekil 1. Anni Albers, Anni Albers, 1949b.

Mevcut dönemde okuldaki birçok kız öğrenci gibi Weimar'daki Dokuma Atölyesi'ne yönlendirilen Anni Albers, öncelikle Georg Muche, Johannes Itten, Paul Klee gibi isimlerden eğitim almıştır (Gonnard, 2019). Dokuma Atölyesi'nde eğitim veren akademisyenlerin resim konusunda uzman olması ve dokuma teknikleri konusuna hâkim herhangi bir akademisyenin olmaması Albers'i resim anlayıșı ile bütünleșen dokuma tasarımları yapmaya yönlendirilmiş olsa da devam eden süreçte eğitmeni olan Gunta Stölzl'den öğrendikleri ile endüstriyel üretime uygun dokuma tasarımlarını ortaya koymuştur. Tasarımcı Gunta Stölzl ile dokuma yapısının inceliklerini öğrenmekle birlikte geometrik desenleri barındıran, atkı iplikleri kadar çözgü ipliklerinin de önem taşıdığı çok katlı modern dokuma kumaşlar üretmeye başlamıştır. Özellikle okulun Dessau'ya taşınmasıyla birlikte teknik anlamda kendini daha da özgür hisseden tasarımcı, ışı̆̆ı yansıtan, ses emilimini kolaylaştıran, kırışmayı önleyen ve bükülme eğilimi fazla olan günümüz için bile yenilikçi sayılabilecek olan dokuma kumaşlar geliştirmeyi başarmıştır. Bununla birlikte Anni Albers, dönemin tekstil endüstrisi için çok yeni olan at kılı, jüt, kâğıt, keten, metalik, selefon ve viskon gibi karışımlara sahip malzemeleri dokuma kumaş tasarımlarında kullanarak (Şekil 2), endüstriyel dokuma kumaşlara yenilikçi bir yaklaşım kazandırmayı başarmıştır (Gürcüm, 2019, s. 199; Weber, Jacob \& Field, 1985, s. 1-120; Weltge, 1993, s. 133).

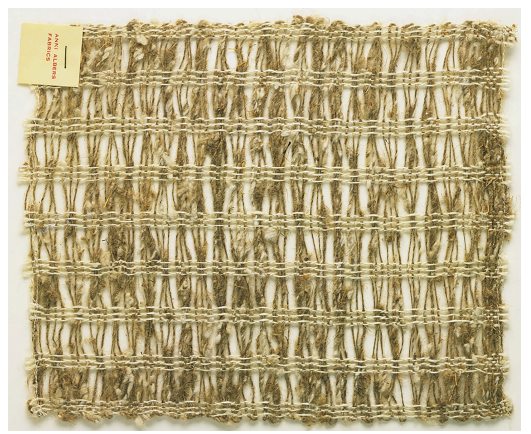

(a)

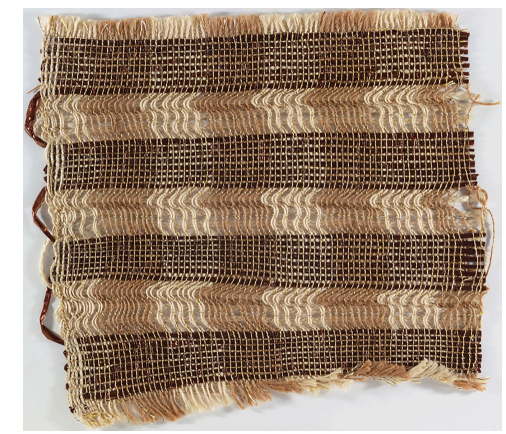

(b)

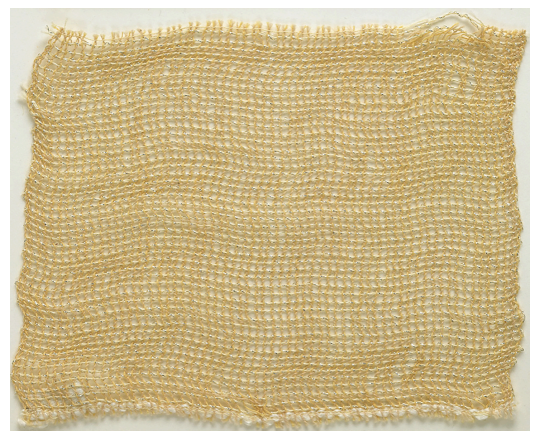

(c)

Şekil 2. a) Endüstriyel dokuma kumaş örneği, A. Albers, tahm. 1933a, b) Endüstriyel dokuma kumaşörneği, A. Albers, 1949a, c) Endüstriyel dokuma kumaş örneği, A. Albers, tahm. 1933b. 
Bauhaus Sanat ve Tasarım Okulu'nda tanıștığı ressam Josef Albers ile evlenen Anni Albers, önceki dönemde Dokuma Atölyesi'nde akademisyen olarak çalışan Gunta Stölzl'ün istifa etmesiyle okulun kapanma sürecine kadar Dokuma Atölyesi'nin başına geçerek bu atölyeyi yönetmiștir. 1933 yılında Almanya'daki siyasi karışıklıklar nedeniyle okulun kapanmasıyla birlikte mimar Philip Johnson'ın davetiyle Albers ve eşi Amerika Birleşik Devletleri'ne göç etmek zorunda kalmışlardır (Troy, 2002, s. 95). Amerika Birleşik Devletleri'ne göç ettikten sonra Black Mountain Koleji'nde (Black Mountain College) akademisyen olarak çalışmaya başlayan Anni Albers, dokuma tasarımlarında deneysel malzemeleri kullanmayı ilke edinerek, sahip olduğu bilgi ve deneyimlerini, yenilikçi ve özgün bir anlayış ışığında öğrencileriyle paylaşmaya devam etmiştir.

Birçok ülkede tekstil tasarımcısı ve akademisyen kimliği ile kişisel sergiler açmış olan Anni Albers ayrıca tekstil tasarımı ile ilgili iki farklı kitaba da (On Designing, 1959 ve On Weaving, 1965) imzasını atmıştır. Bununla birlikte, özellikle Kuzey ve Güney Amerika'daki birçok bölgeye seyahat eden Anni Albers, Güney Amerika Dokumacılığı üzerine de uzmanlaşmıştır. Amerika Birleşik Devletleri'ne göç ettikten sonra endüstriyel dokuma kumaş tasarımları konusundaki çalışmalarını sürdüren tasarımcı, aynı zamanda Rosenthal ve Knoll gibi dönemin önemli kumaș firmaları için endüstriyel dokuma kumaș tasarımları gerçekleștirmiştir (Gonnard, 2019). 1994 yılında Amerika Birleşik Devletleri'nin Connecticut kentinde hayata gözlerini yuman Anni Albers, 20. yüzyılın en önemli tekstil tasarımclarından birisi olarak nitelendirilmektedir. Anni Albers'in eşi Josef Albers tarafından 1971 yılında Amerika Birleşik Devletleri'nde kurulmuş olan Josef ve Anni Albers Vakfı, günümüzde hala yaptıkları çalışmalarla bu isimleri yaşatmaktadır.

\subsection{Otti Berger}

Doğum adı Otilija Ester olarak bilinen (Fischer, 2013) Otti Berger (Şekil 3), 1898 yılında dönemin Avusturya-Macaristan İmparatorluğu'nun bir parçası olan günümüzde ise Hırvatistan sınırları içerisinde yer alan Zmajevac kentinde dünyaya gelmiștir (Mlikota, 2009, s. 271). Viyana'da lise eğitimini tamamladıktan sonra mevcut dönemdeki adı ile Zagreb Kraliyet Sanat ve El Sanatları Akademisi olan, günümüzdeki adıyla ise Zagreb Güzel Sanatlar Akademisi'ne (Akademija likovnih umjetnosti u Zagrebu) girerek, bu okulda sanat eğitimini tamamlamıştır. Eğitimini tamamlayan Berger, Zagreb'te kendi çalışmalarını bir süre sürdürmüş, daha sonra ise Zagreb Kraliyet Sanat ve El Sanatları Akademisi'ndeki akademisyenlerin desteği ile Dessau'da bulunan Bauhaus Sanat ve Tasarım Okulu'na girerek, bu okulda eğitimine devam etmiştir (Rössler \& Otto, 2019, s. 96).

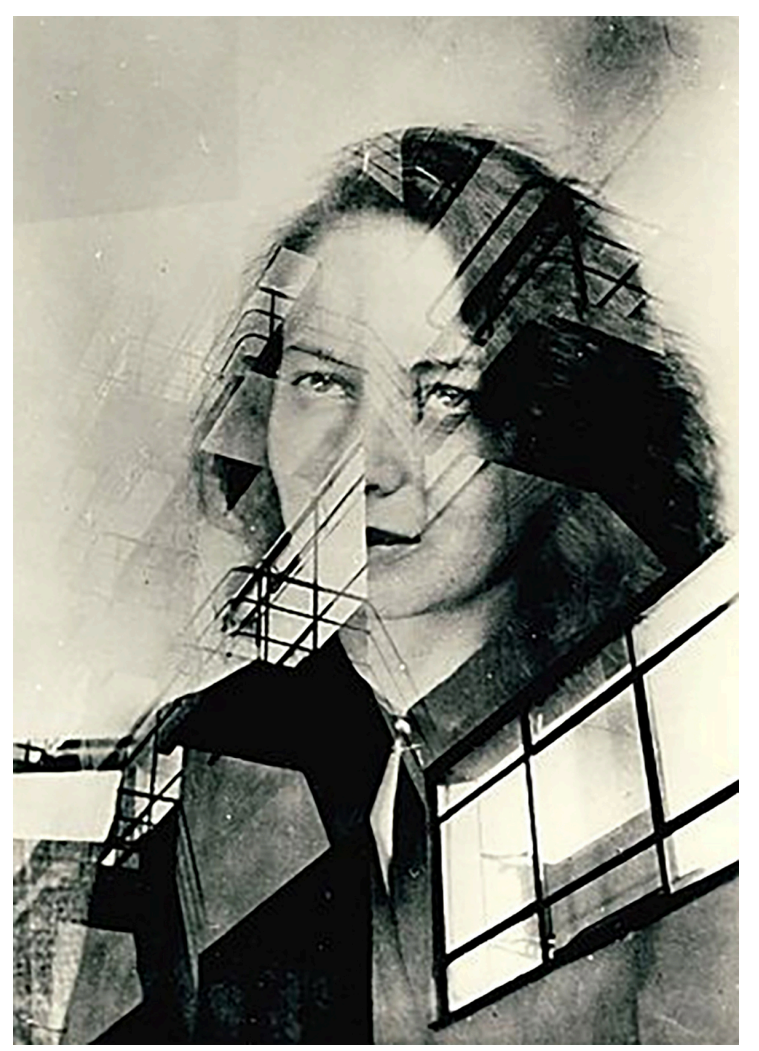

Şekil 3. Otti Berger (Weltge, 1993, s. 89). 
Bauhaus Sanat ve Tasarım Okulu bünyesinde bulunan Dokuma Atölyesi'nde eğitim almaya bașlayan Berger, mevcut dönemde László Moholy-Nagy, Wassily Wassilyevich Kandinsky ve Paul Klee gibi kült isimlerin yanı sıra dokuma tasarımında öncü bir isim olarak gösterilebilecek arkadaşı Gunta Stölzl'den de dersler almıştır. Dessau'da bulunan Dokuma Atölyesi'ndeki en parlak öğrencilerden birisi olarak gösterilen tasarımcı, ortaya koyduğu endüstriyel dokuma kumaş tasarımları ile çağın ötesinde gösterilebilecek modern bir çizgi yakalamayı başarmıştır (Weibel, Leitner, Bajkay \& David, 2005, s. 76).

Otti Berger Berger'i sahip olduğu teknik altyapı doğrultusunda plastik malzemeleri tekstil materyali olarak kullanarak dokuma kumaş tasarımları geliştirmeye yönlendirmiştir. Yenilikçi dokuma kumaş tasarımındaki arayışları tasarımcıyı farklı materyallerle deneysel çalışmalara yönlendirirken, ürettiği bu yenilikçi dokuma kumaş tasarımlarının seri üretim içerisinde endüstriye nasıl adapte edilebileceği konusunda çalışmalar yaparak çözüm geliştirmesine de neden olmuştur (Şekil 4).

Tasarımcının özellikle döşemelik kumaş koleksiyonları dikkat çekmiştir. 1936 yılında Otti Berger, Döşemelik Çift Katlı Kumaş (Möbelstoff-Doppelgewebe) adını verdiği dokuma kumaş koleksiyonu için bir patent başvurusunda bulunmuştur (Smith, 2008, s. 54-73). Bu yönüyle Berger'in, tekstil tasarımına patent olgusunu sokan öncü tasarımcılardan birisi olduğu görülmektedir.

Bauhaus Sanat ve Tasarım Okulu bünyesinde yer alan Dokuma Atölyesi'nde akademisyenlik yapan Gunta Stölzl'ün bir dönem atölyeden ayrılması ile bu atölyenin başına geçen Otti Berger, aynı zamanda birçok tekstil firmasına dokuma kumaş tasarımı koleksiyonu üretmiş ve danışmanlık hizmeti sağlamıştır. Bunun yanı sıra yine Bauhaus Sanat ve Tasarım Okulu'ndan yetişen bir başka tasarımcı Lilly Reich ile bir müddet çalıştıktan sonra 1932 yılında Berlin'de Otti Berger Tekstil Atölyesi (Otti Berger Atelier für Textilien) adlı bireysel atölyesini kurmuştur. Kendine ait atölyesinde endüstriyel anlamda metraj dokuma kumaş tasarımları üreten tasarımcı, Almanya'da ortaya çıkan siyasi karışıklıklar nedeniyle 1936 yılında atölyesini kapatmak durumunda kalmıştır. Otti Berger bu süreçten sonra nişanlısı Ludwig Hiberseimer ve Bauhaus Sanat ve Tasarım Okulu'nda görev yapmış bazı akademisyenlerle birlikte Berlin'i terk ederek Londra'ya göç etmiştir (Fischer, 2013). Dönemin zor şartları nedeniyle Londra'da kalıcı olamayan Berger, annesinin yaşadığı sağlık problemleri nedeniyle 1938 yılında doğduğu kent olan Zmajevac'a geri dönmüştür. 1944 yılında ise Avrupa'nın birçok bölgesini işgal eden birlikler tarafından ailesi ile birlikte Polonya'da bulunan Auschwitz Toplama Kampı'na götürülen Otti Berger burada hayatını kaybetmiștir (Mlikota, 2009, s. 278).

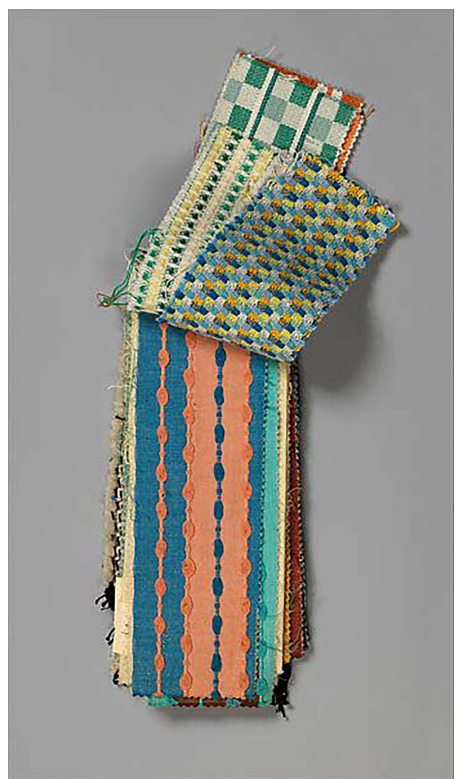

(a)

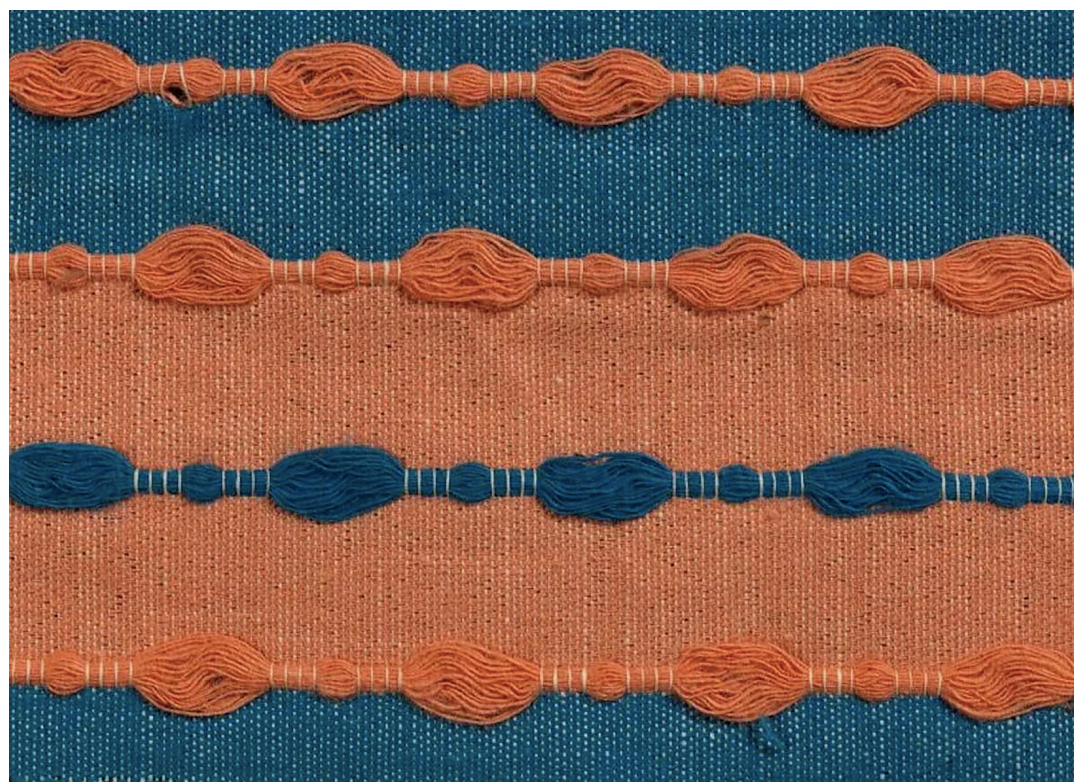

(b)

Şekil 4. a) Dokuma kumaş kataloğu, O. Berger, tahm. 1930a, b) Endüstriyel dokuma kumaş örneği, O. Berger, tahm. 1930b.

Otti Berger, öncü ve yenilikçi endüstriyel dokuma kumaş tasarımları ile döneminin tekstil endüstrisinin gelişmesine çok önemli katkı sağlamıștır. Tasarımcının geliștirdiği birçok dokuma kumaș tasarımı Almanya'da bulunan Bauhaus Arşivi Tasarım Müzesi'nin (Bauhaus-Archiv Museum für Gestaltung Berlin) yanı sıra Amerika Birleşik Devletleri'nde bulunan Metropolitan Müzesi (The Metropolitan Museum of Art) ve Şikago Sanat Enstitüsü (The Arts Institute of Chicago) gibi mekânlarda sergilenmektedir. 


\subsection{Gunta Stölzl}

Alman tekstil tasarımcısı Gunta Stölzl (Şekil 5) 1897 yılında Münih’te dünyaya gelmiştir. Öğretmen olan bir baba ve okul müdürü olan bir annenin kızı olan Stölzl, lise eğitimini tamamladıktan sonra 1914 yılında Münih Kraliyet Uygulamalı Sanatlar Okulu'na (Königliche Kunstgewerbeschule München) girmiştir. Bu okulda cam, seramik ve dekoratif sanatlar üzerine çeşitli atölyelerde çalıșmıştır (Müller, 2009, s. 42). Mevcut dönemde Avrupa'yı etkisi altına alan I. Dünya Savaşı nedeniyle 1917 yılında Kızılhaç için gönüllü hemşire olarak çalışmış olan Stölzl, 1919 yılında Almanya'ya geri dönmüş ve Johannes Itten'in hazırlık kurslarına katılmış ve sonrasında Weimar'da bulunan Bauhaus Sanat ve Tasarım Okulu'na kabul edilerek burada eğitimine başlamıştır (Weltge, 1993, s. 46).

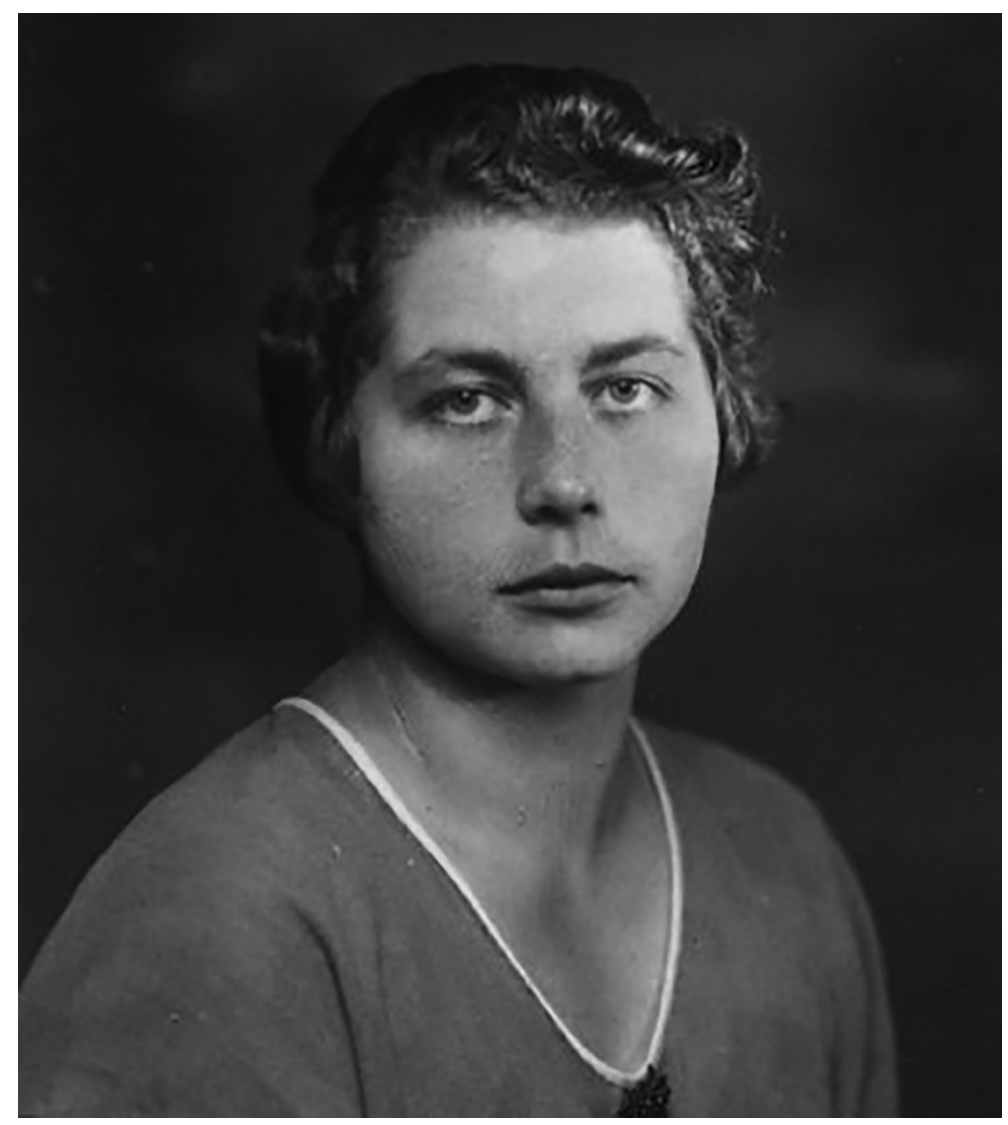

Şekil 5. Gunta Stölzl, Gunta Stölzl, 1915-1919.

Bauhaus Sanat ve Tasarım Okulu bünyesinde yer alan ve okul öğrencileri arasında kadın bölümü olarak adlandırılan Dokuma Atölyesi'nde eğitimine başlayan tasarımcı, lider özelliği ve derslerdeki çabası sayesinde ön plana çıkmıştır. Johannes Itten, Paul Klee, Wassily Wassilyevich Kandinsky gibi isimlerden almış olduğu renk teorisi, görsel algı, soyut sanata ilişkin derslerin çıktılarını dokuma tasarımı ile şekillendirmiş ve böylece dönemin tekstil endüstrisine öncülük edecek endüstriyel dokuma kumaşlar üretmiştir (Arslan, 2019, s. 349). Gunta Stölzl'ün öğrencilik yıllarında Dokuma Atölyesi'nin başında olan Georg Muche'un zanaat kavramına çok az ilgi duymasından yakınmış ve teknik anlamda kendisinden çok da faydalanamadığını belirtmiștir (Weltge, 1993, s. 49). Stölzl tekstil tasarımı eğitiminin, Dokuma Atölyesi'nde çalıştığı akademisyenlerden form ustası Georg Muche ya da zanaat ustası Helene Börner öğretileri kadar keskin bir anlayışta olmaması gerektiğine, bu eğitimi verecek kişilerin her iki yapıyı da bir arada devam ettirebilecek donanıma sahip kişiler tarafından verilmesi gerekliliğine inanmıştır.

Tasarımcl, 1924 yılında Johannes Itten'in yönlendirmeleri sonucunda Krefeld kentinde tekstil boyamacılığı ve üretim yöntemleri üzerine kurslara katılmış, böylece kendisini endüstriyel tekstil üretimi anlamında daha da geliştirmiştir. Ayrıca Gunta Stölzl, İsviçre'nin Zürih kenti yakınlarında bulunan Herlliberg kasabasında dokuma atölyeleri kurulmasına da yardımcı olmuştur (Bröhan \& Berg, 2001, s. 84). Bu süreç tasarımcının endüstriyel dokuma tasarımı açısından daha gelişmesini sağlamıștır. 
1927 yılında Georg Muche, Dokuma Atölyesi'nden ayrılmış ve böylece Gunta Stölzl bu atölyenin başına geçerek uzun bir süre atölyenin yöneticiliğini üstlenmiştir. Atölyeye çok faydası olan ve dokuma tasarımı bilgisi ile endüstriyel boyutta dokuma kumaş tasarımlarının oluşmasında önemli derecede katkıları olan Stölzl, Dokuma Atölyesi'nden çıkan ürünlerin üretimi ve satışı konusunda da çok çaba sarf etmiştir. Gunta Stölzl, Dessau'daki Dokuma Atölyesi'nin sahip olduğu hem armür hem de jakar yapılı dokuma tezgâhlarının yanında boya atölyelerinden yararlanarak çağın gereksinimini karşlayan özgün dokuma kumaş tasarımlarının ortaya çıkmasını sağlamıștır. Bu süreçte de en fazla desteği aynı atölyeden yetiştiği ve daha sonra eğitmenliklerini yaptığı Anni Albers, Otti Berger ve Benita Koch-Otte gibi hemcinslerinden görmüștür. Alman tekstil tasarımcısı Gunta Stölzl, aynı zamanda mevcut atölyeden yetişen ilk kadın akademisyendir. Dokuma tasarımının tasarımcının tercih ettiği malzemelerle şekillendirdiği yapılandırdığı estetik bir çıktı olduğunu ileri süren bir tasarımcıdır. Ürettiği dokuma tasarımlarının fayda sağlayacak bir ürüne dönüşmesini amaçlayarak tasarladığını savunmuştur. Bu bağlamda; renk, doku, yapı gibi kavramları bir arada değerlendirmiş; bununla birlikte dokuma kumaşların aşınması, esnekliği, ışık ve ses emilimi gibi teknik yönleriyle de ilgilenmiştir. Ayrıca dokuma kumaş tasarımında deneyselliği ön planda tutarak dokuyu ön plana çıkaracak selefon, fiberglass, metal vb. içeriğe sahip alışılmışın dışında lifleri farklı dokuma yapılardaki tasarımlarında kullanmıștır (Șekil 6). Sahip olduğu dokuma tezgâhlarında teknikler geliștirerek Karmaşık biçimsel kompozisyonları ile özgün dokuma kumaş yapıları oluşturduğu tasarımlarında başarılı sonuçlar elde etmiştir. Bu yönüyle Dokuma Atölyesi, Gunta Stölzl liderliğinde altın çağını yaşamıştır (Droste, 2002, s.73; Stölzl, 2009, s. 11, 70; Weltge, 1993, s. 46-50).

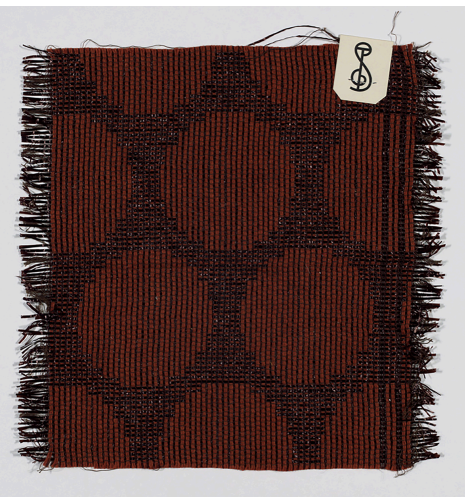

(a)

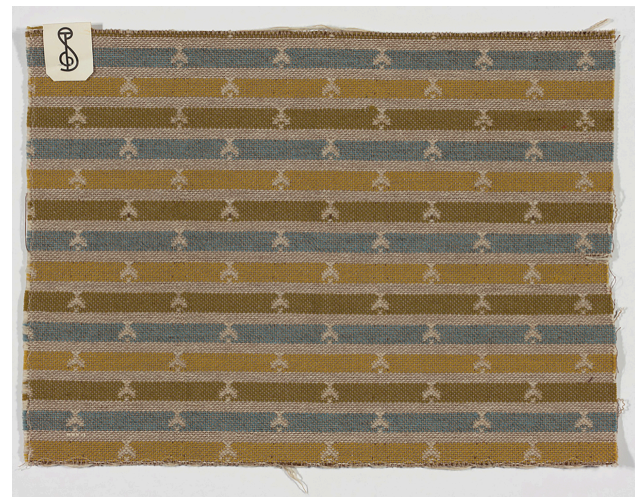

(b)

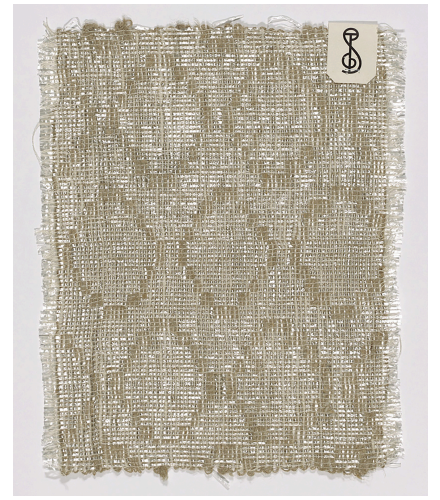

(c)

Şekil 6. a) Döşemelik dokuma kumaş örneği (selefon, pamuk, ipek ve ipek floş), G. Stölzl, 1939, b) Endüstriyel dokuma kumaş örneği (yün ve pamuk), G. Stölzl, 1932-1966a, c) Döşemelik dokuma kumaş örneği (selefon, pamuk ve keten), G. Stölzl, 1932-1966b.

1931 yılında Almanya'da beliren siyasi karışıklıklar nedeniyle okuldaki görevinden ayrılmak zorunda kalan tasarımcı, eşi mimar Arieh Sharon ve kızları Ya'el Sharon ile birlikte İsviçre'ye göç etmişlerdir. Zürih kentinde yaşamaya başlayan Stölzl, burada Dokuma Atölyesi kökenli Gertrud Preiswerk ve Heinrich-Otto Hürlimann ile ortak olarak bir dokuma kumaş atölyesi kurmuşlardır (Droste, Marion \& Fiedler, 1987, s. 24). Sonraki süreçte, 1967 yılına kadar ortak olduğu bu atölyeyi tek başına yürütmüștür (Stölzl, 2009, s. 10). Bununla birlikte duvar halıları üreterek tekstil sanatçısı olarak çalıșmış ve 1983 yılında İsviçre'nin Zürih kentinde hayata gözlerini yummuştur. Tasarımcının günümüz tekstil endüstrisine ışı tutan kumaş tasarımları günümüzde birçok saygın müzede sergilenmektedir.

\section{Sonuç}

Sanayi Devrimi ve Arts and Crafts Hareketi ile birlikte 20. yüzyılın ilk yarısında ortaya çıkan modernizm kavramının getirileri sonucunda dönemin eğitim sistemi içerisinde gelişen tekstil tasarımı anlayışı, dokuma kumaş tasarımına yeni bir soluk kazandırarak yeni bir dönemin başlamasına öncülük etmiştir. Tekstil endüstrisindeki tasarım süreçleri içerisinde makineleşme ile zanaatın bir arada kullanılmasının gerekliliğini savunan bu yeni anlayış, aynı zamanda söylemleri ile sanat ve zanaat kavramlarının da ayrılmaz bir bütün olduğu fikrini ortaya koymuștur. Bu bağlamda, öncelikle Avrupa'da beliren endüstriyel üretim için başka bir ifade ile endüstriyel üretime uygun yenilikçi fikirlerle tasarım yapmak düşüncesi tekstil tasarımcısının endüstriyel üretim sürecinde daha da değer kazanan bir konuma gelmesini sağlamıștır.

1919 yılında Almanya'nın Weimar kentinde kurulup sonraki süreçlerde ortaya çıkan siyasi karışıklıklar nedeniyle Dessau ve Berlin gibi kentlerde konumlanmış olan ve mevcut düşünceye öncülük eden Bauhaus 
Sanat ve Tasarım Okulu bünyesinde yer alan Dokuma Atölyesi'nde günümüz endüstriyel tekstil tasarımı anlayışının temelleri atılmıştır. Bu atölyede aldıkları çok yönlü sanat ve uygulamalı tasarım eğitimi sayesinde endüstriyel üretime yönelik geliştirdikleri dokuma kumaş tasarımı örnekleriyle Anni Albers, Otti Berger ve Gunta Stölzl gibi öncü tekstil tasarımcıları ön plana çıkardığımızda, günümüz tekstil tasarımcısının yenilikçi tasarımlar geliştirme çabasının yansıtıldığını görmek mümkün olacaktır. Sözü edilen kișiler, hem tasarımcı hem de akademisyen kimlikleriyle ayrıca yenilikçi bakıș açıları ve yaklaşımlarıyla dokuma tasarımına katkı sağlayarak dokuma kumaş tasarımının endüstriyel üretime değer katan yönlerini öne çıkarmışlardır. Atkı ve çözgü sisteminden oluşan dokuma anlayışının endüstriyel üretime uygun tezgâhlarla geliştirilebilir yönlerini keşfeden bu öncü isimler, dokuma tezgâhındaki deneyimleme süreçlerinde kendilerini daha önce hiç görülmemiş tasarımlar ile geliştikleri bir sürecin içerisinde bulmuşlardır. Dokuma kumaş yapıları ile birlikte estetik değerler taşıyan tasarımlarda o döneme kadar kullanılmamış yenilikçi malzemelerin yer alması, tasarımcıların düşüncelerinde ve uygulamalarında deneysel arayışlarla birlikte kullanım alanına yönelik endüstriyel çözümlerin de konu olduğunu ortaya çıkarmıştır. Bununla birlikte Anni Albers, Otti Berger ve Gunta Stölzl gibi tekstil tasarımcılarının ürettikleri armürlü ve jakarlı üretim yöntemine uygun yenilikçi bu tasarımlar endüstriyel kumaş üretimi yapan firmaların dikkatini çekmiş ve bu tasarımlar dönemin tekstil endüstrisinde yer alan çeşitli firmalar tarafından metraj olarak da üretilmiştir.

Bauhaus Sanat ve Tasarım Okulu bünyesinde yer alan Dokuma Atölyesi'nde yetişen tekstil tasarımcılarının estetik yaklaşımları ve endüstriyel üretime bakış açıları günümüz dokuma kumaş endüstrisinin tasarım düzeyini oldukça şekillendirmiştir. Bu atölyede yetişen ve bu çalışmada ele alınan Anni Albers, Otti Berger ve Gunta Stölzl gibi öncü tekstil tasarımcılarının yeni fikirler ve sıra dışı malzemelerle geliştirdikleri yenilikçi tasarımların, endüstriyel üretime uygun çözümlerle geliştirilerek tasarım niteliği yüksek ürünler üretmesinin, mevcut Dokuma Atölyesi'nde ortaya çıkan bir tasarım yaklaşımı olduğu anlaşılmaktadır. Bu yenilikçi tasarım yaklașımı bugün hala çeșitli Güzel Sanatlar Fakültelerinin tekstil tasarımı eğitimine sahip uygulamalı atölye derslerinde bir eğitim yöntemi olarak devam ettirilmektedir. Bu bağlamda, günümüzde birçok farklı ülkede tekstil tasarımı eğitimi veren bölümlerinin Bauhaus Sanat ve Tasarım Okulu bünyesinde yer alan Dokuma Atölyesi'ni model alan eğitim programlarına sahip olduğu söylenebilir.

Bunun yanı sıra söz konusu Dokuma Atölyesi'nden yetişen tasarımcıların endüstriyel üretime uygun dokuma kumaş tasarımı numuneleri ile kumaş katalogları oluşturması, bu kumaş kataloglarının dönemin tekstil endüstrisinde yer alan firmalara sunulması, sergi ve fuar gibi etkinlikler ile tüketicilere ulaştırılması günümüz eğitim modellerine ve endüstriyel sunum biçimlerine öncülük eden fikir ve uygulamalardır. Ayrıca günümüzde tekstil tasarımcılarının firmalarla endüstriyel işbirliklerine giderek, dokuma kumaş tasarımını geliştirmeye yönelik çalışmaların temellerinin de mevcut atölye ile ortaya konulduğu görülmektedir. Sonuç olarak günümüzde tekstil tasarımcılarının endüstriyel üretim amaçlı dokuma kumaş tasarımı konusundaki yenilikçi arayışlarının, araştırma ve geliştirme çalışmalarının, dünya çapında gerçekleştirilen kumaş fuarlarının, tekstil endüstrisine katkı sağlamak amacıyla gerçekleştirilen alana ilişkin tasarım yarışmalarının ve üniversitelerin tekstil tasarımı eğitimi içeriklerinin köklerine bakıldığında bu yapının mevcut Dokuma Atölyesi'nden çıkan fikirler ışığında gelişim gösterdiği görülmektedir.

\section{Kaynakça}

Acar, S. (2004). Dokuma yapıların görsel ve fiziksel özelliklerinin oluşumunu sağlayan faktörlerin tasarım açısından incelenmesi (Yüksek lisans tezi). Dokuz Eylül Üniversitesi Güzel Sanatlar Enstitüsü, İzmir.

Acar, S. (2013). Jack Lenor Larsen: İç mekân tekstili tasarımında bir öncü. İnönü Üniversitesi Sanat ve Tasarım Dergisi, 3(7), 81-91.

Akbostancı, İ. (2014). 20. ve 21. yüzyıllarda tekstil baskı tasarımı ve üretiminin değișen tanımı. SanatTasarım Dergisi, 5, s. 31-41. doi: 10.17490/Sanat.201559167

Albers, A. [tahm. 1933a] Woven fabric sample [Linen weaving fabric]. The Museum of Modern Art, Manhattan, New York, The USA. Erişim adresi: https://www.moma.org/collection/works/3691

Albers, A. [tahm. 1933b]. Woven fabric sample [Cotton and metallic thread weaving wabric]. The Museum of Modern Art, Manhattan, New York, The USA. Erişim adresi: https://www.moma.org/collection/works/3787

Albers, A. (1949a). Woven fabric sample [Horse hair, jute, cellophane and cotton weaving fabric]. The Museum of Modern Art, Manhattan, New York, The USA. Erişim adresi: https://www.moma.org/collection/works/3587 
Albers, A. (1949b). Anni Albers [Photograph]. The Museum of Modern Art, Manhattan, New York, The USA. Erişim adresi: https://www.moma.org/artists/96?=undefined\&page=\&direction=fwd

Alyanak, Ş. (1998). Bauhaus dokuyor: Bauhaus'un tekstil atölyeleri. Arredamento Mimarlık, s. 114-119.

Anscombe, I. (1991). Arts and crafts style. London: Phaidon Press.

Arslan, S. (2019). Bauhaus 100. yılında: Bauhaus dokuma atölyesi ve dokuma kültürünün çağdaş sanata dâhil edilme süreci. Uluslararası Sosyal Araştırmalar Dergisi, 65, s. 187-203. doi: http://dx.doi.org/10.17719/jisr.2019.3451

Aslan, R. (2015). Gerçeküstücü harekette ütopya kavramı. Trakya Üniversitesi Sosyal Bilimler Dergisi, 17(2), 37-47.

Baines, E. (1835). History of the cotton manufacture in Great Britain. London: H. Fisher, R. Fisher and P. Jackson.

Berger, O. [tahm. 1930a]. Woven fabric catalogue [Weaving Fabric]. The Metropolitan Museum of Art, New York, The USA. Erişim adresi: https://www.metmuseum.org/art/collection/search/488834

Berger, 0. [tahm. 1930b]. Woven fabric sample [Weaving Fabric]. The Metropolitan Museum of Art, New York, The USA. Erișim adresi: https://www.metmuseum.org/art/collection/search/488834

Bilgin, İ. (2009). Bauhaus'un zamanı ve yeri. A., Artun ve E., Aliçavuşoğlu (Ed.), Bauhaus: Modernleşmenin tasarımı Türkiye'de mimarlık, sanat, tasarım eğitimi ve Bauhaus içinde (s. 95-109), İstanbul: İletişim Yayınları.

Brent, F. (2018, 19 Aralık). Anni Albers's fabric of belief at the Tate: European and American modernism woven into the warp and weft of grief. Tablet Magazine. Erişim adresi: https://www.tabletmag.com/sections/arts-letters/articles/anni-albers-tate-modern

Bröhan, T. \& Berg, T. (2001). Design classics 1880-1930. New York: Taschen.

Campbell, G. (2006). The grove encyclopedia of decorative arts: Volume I. New York: Oxford University Press.

Droste, M., Marion, E. \& Fiedler, J. (1987). Gunta Stölzl: Weberei am Bauhaus unda us eigener werkstatt. Berlin: Kupfergraben Verlag.

Droste, M. (2002). Bauhaus 1919-1933. Berlin: Taschen GmbH.

Erkmen, N. (2009). Bauhaus ve Marmara Ünivesitesi Güzel Sanatlar Fakültesi. A., Artun ve E., Aliçavuşoğlu (Ed.), Bauhaus: Modernleşmenin tasarımı Türkiye'de mimarlık, sanat, tasarım eğitimi ve Bauhaus içinde (s. 17-20), İstanbul: İletişim Yayınları.

Espinasse, F. (1874). Lancashire worthies. London: Simpkin, Marshall \& Co.

Essinger, J. (2004). Jacquard's web: How a hand-loom led to the birth of the information age. Oxford: Oxford University Press.

Fischer, L. (2013, 25 Ağustos). Otti (Otilija Ester) Berger: 1898-1944. Online Magazine für Frauen AVIVA. Erişim adresi: berlin.de/aviva/content_Women\%20+\%20Work.php?id=1418566

https://www.aviva-

Fitton, S. (1989). The Arkwrights: Spinners of fortune. Manchaster: Manchester University Press.

Forgács, É. (2017). Bauhaus 1919-1933 (A. Tümertekin, Çev.). İstanbul: Janus Yayınları.

Gonnard, C. (2019, 3 Mart). Anni Albers: Artiste textile, designer et théoricienne de l'art allemande. Aware. Erişim adresi: https://awarewomenartists.com/artiste/anni-albers/

Gropius, W. (2002). Modern mimarlığın öncüleri: Walter Gropius ve Bauhaus (N. Togay, Çev.). İstanbul: Boyut Kitapları.

Günay, D. (2002). Sanayi ve sanayi tarihi. Mimar ve Mühendis Dergisi, 31, 8-14.

Gür Üstüner, S. (2017). Tekstil tasarım tarihine genel bir bakış. Sanat-Tasarım Dergisi, 8, s. 49-58. doi: 10.17490/Sanat.2018.21

Gür Üstüner, S. (2018). Tekstilde sanat ve tasarımın endüstri ile buluşması: Bauhaus dokuma atölyesi. Sosyal Bilimler Dergisi, 5(19), 235-252. 
Gürcüm, B. (2019). Bauhaus dokuma atölyesi üzerine. The Journal of Academic Social Science Studies, 77, s. 187-203. doi: 10.9761/JASSS39899

Gürcüm, B. ve Öniş, A. (2017). Bauhaus'da bir dokuma ustası: Gunta Stölzl. Uluslararası Sosyal Araştırmalar Dergisi, 51, s. 400-418. doi: http://dx.doi.org/10.17719/jisr.2017.1776

Hounshell, D. A. (1985). From the American system to mass production 1800-1932: The development of manufacturing technology in the United States. Baltimore: The Johns Hopkins University Press.

İşpiroğlu, N. ve İşpiroğlu, M. (1979). Sanatta devrim: Yansıtmacılıktan oluşturmaya doğru. İstanbul: Ada Yayınları

Jackson, L. (1998). The sixties: Decade of design revolution. London: Phaidon Press.

Jackson, L. (2002). Twentieth-century pattern design. New York: Princeton Architectural Press.

Landes, D. S. (1988). The unbound prometheus: Technological change and industrial development in Western Europe from 1750 to the present. New York: Cambridge University Press.

Marsden, E. (1895). Cotton weaving: Its development, principles and practice. London: George Bell \& Sons.

Mlikota, A. (2009). Otti Berger-Hrvatska umjetnica iz tekstilne radionice Bauhausa. Radovi Instituta za povijest umjetnosti, 33(2009), 271-282.

Müller, U. (2009). Bauhaus women: Art, handicraft, design. Paris: Flammarion.

Özay, S. (2001). Dünden bugüne dokuma resim sanatı. Ankara: Kültür Bakanlığı Yayınları.

Parry, L. (1983). William Morris textiles. Newyork: The Viking Press.

Read, H. (1973). Sanat ve endüstri (N. Bayazıt, Çev.). İstanbul: İ.T.Ü. Matbaası.

Reif, R. (1984, 10 Mayıs). Anni Albers, 94, textile artist and the widow of Josef Albers. The New York Times, s. 8.

Rössler, P. \& Otto, E. (2019). Frauen am Bauhaus: Wegweisende künstlerinnen der moderne. München: Knesebeck Verlag.

Siebenbrodt, M. \& Schöbe, L. (2009). Bauhaus 1919-1933: Weimar-Dessau-Berlin. New York: Parkstone Press International.

Smith, T. (2008). Anonymous textiles, patented domains: The invention (and death) of an author. Art Journal, 2(67), s. 54-73. doi: https://doi.org/10.1080/00043249.2008.10791304

Stölzl, G. (1915-1919). Gunta Stölzl [Photograph]. Bauhaus-Archiv Museum für Gestaltung Berlin, Berlin Germany. Erişim adresi: https://www.guntastolzl.org/Works/Early-Period-1915-1919/EarlyPhotos/i-qXMnJMw

Stölzl, G. (1939). Upholstery woven fabric sample (cellophane, cotton, silk and silk floss) [Weaving Fabric]. The Museum of Modern Art, Manhattan, New York, The USA. Erişim adresi: https://www.moma.org/collection/works/4001

Stölzl, G. (1932-1966a). Woven fabric sample [Wool and cotton weaving fabric]. The Museum of Modern Art, Manhattan, New York, The USA. Erișim adresi: https://www.moma.org/collection/works/4013

Stölzl, G. (1932-1966b). Upholstery woven fabric sample [Cellophane, cotton and linen weaving fabric]. The Museum of Modern Art, Manhattan, New York, The USA. Erişim adresi: https://www.moma.org/collection/works/3997

Stölzl, G. (2009). Gunta Stölzl: Bauhaus master. New York: The Museum of Modern Art.

Timmins, G. (1993). The last shift: The decline of handloom weaving in nineteenth-century Lancashire. Manchaster: Manchester University Press.

Troy, V. G. (2002). Anni Albers and ancient American textiles: From Bauhaus to Black Mountain. Aldershot: Ashgate Publishing Company.

Weber, N. F., Jacob, M. J. \& Field, R. S. (1985). The woven and graphic art of Anni Albers. Washington D.C.: Smithsonian Institution Press. 
Weibel, P., Leitner, B., Bajkay, É. \& David, C. (2005). Perception movement. In Peter W. (Ed.), Beyond art, a third culture: A comparative study in cultures, art, and science in 20th century Austria and Hungary (p. 12-153), Wien: Springer Science \& Business Media.

Weltge, S. W. (1993). Bauhaus textiles: Women artist and the weaving workshop. London: Thames and Hudson.

Yaşar, N. (2019). Bauhaus'dan Black Mountain Koleji'ne Anni Albers dokumaları. Van Yüzüncü Yıl Üniversitesi Sosyal Bilimler Enstitüsü Dergisi, 44, 131-152.

Yaylalı, H. (2000, Nisan). Bauhaus Okulu. Art Decor, s. 106-120. 